\title{
TESTING OF JEROVEC SAND AND DEFINING ITS CRITICAL STATE LINE
}

\section{Jure Ofak}

Scientiffic paper/ Znanstveni rad

Geotehnicki studio d.o.o., M.C.E.

Corresponding author: jure.ofak@geotehnicki-studio.hr

\section{Sonja Zlatović}

Zagreb University of Applied Sciences, Ph.D.

Igor Sokolić

Geotehnicki studio d.o.o., Ph.D.

\begin{abstract}
The behavior of sand largely depends on the initial state, water content, drainage conditions, and type of action on the sand. The dominant mechanism that governs sand behavior is dilatancy, the volume change during shearing. Owing to dilatancy, dense sand samples attain greater strength during shearing compared to loose samples. Investigation of the sand behavior shows that the final strength during shearing, for the sand samples starting from the same initial state of stress, tends to be independent of the initial void ratio. This final state is called the critical state, or steady state, and can be well described by the critical state line. The main goal of this research is to investigate the behavior of clean sand from Jerovec under triaxial shearing and to derive its critical state line. The behavior of sand is investigated for different initial states (initial densities and state of stress) and for different drainage conditions (consolidated isotropically drained (CID) test and consolidated isotropically undrained (CIU) test). The test results are presented along with all the laboratory tests performed on Jerovec sand (grain-size distribution, specific gravity, minimum and maximum void ratio). The critical state line is compared with those of other sands available in the literature.
\end{abstract}

Keywords: triaxial test; drained and undrained conditions; initial state of compacted sand; isotropic compression; shear stress-strain curve; stiffness and strength

\section{ISPITIVANJE PIJESKA JEROVEC I ODREĐIVANJE LINIJE KRITIČNOG STANJA}

Sažetak: Ponašanje pijeska znatno ovisi o stanju u kojemu se pijesak nalazi, sadržaju vode u pijesku i uvjetima dreniranja vode, te vrsti djelovanja na pijesak. Dominantan mehanizam koji utječe na ponašanje pijeska je dilatacija, svojstvo zrnatog materijala da mijenja volumen zbog djelovanja čistog smicanja. Zbog djelovanja dilatacije, zbijeni uzorci pijeska postižu veću čvrstoću prilikom smicanja u odnosu na rahle. Ispitivanja pokazuju da neovisno o početnoj zbijenosti, uzorci pijeska koji se smiču iz istog početnog stanja naprezanja, postižu jednaku čvrstoću za konačno stanje. Navedeno stanje naziva se kritičnim stanjem, a može se dobro opisati linijom kritičnog stanja. Svrha istraživanja u ovome radu bila je ispitivanje ponašanja pijeska Jerovec u uvjetima troosnog smicanja, te određivanje linije kritičnog stanja. Ispitano je ponašanje uzoraka za različito početno stanje zbijenosti i izotropnog naprezanja te različite uvjete dreniranosti (drenirani - CID pokus, nedrenirani - CIU pokusi). U radu su prikazani rezultati ispitivanja u troosnom uređaju te rezultati ispitivanja fizičkih karakteristika pijeska (granulometrijski sastav, minimalna i maksimalna zbijenost, specifična težina čvrstih čestica). Linija kritičnog stanja uspoređena je s kritičnim stanjem za slične pijeske dostupne u literaturi.

Ključne riječi: ispitivanje u troosnom uređaju; drenirani i nedrenirani uvjeti; početno stanje zbijenosti pijeska; izotropna kompresija; naponsko deformacijska krivulja smicanja; krutost i čvrstoća. 


\section{INTRODUCTION}

The behavior of sand largely depends on the initial state, water content, drainage conditions, and type of action on the sand. The main goal of this research is to investigate the behavior of quartz sand from Jerovec under triaxial shearing. The sand is a commercial product, dry quartz sand $100-0,1 / \mathrm{Smm}$ available from the local supplier IGM Pješčara Jerovec d.0.o., which gives the great opportunity to have quite homogenous material in sufficient amount to perform a wide range of laboratory tests. The first part of the investigation is to determine the physical characteristics of the sand (relative particle density, grading curve, minimum and maximum void ratio, mineralogy, and shape of particles) and to define the procedure for sand sample installation. Then, the sand behavior is investigated via a triaxial test. In total, nine tests were performed with different initial states (initial density and initial state of stress) and drainage conditions (four drained triaxial tests - consolidated isotropically drained (CID) and five undrained triaxial tests - consolidated isotropically undrained (CIU)). All tests were performed to the axial displacement limit of $20 \%$ for the samples to reach the so-called critical state. A critical state is the state in which the material shears under a constant state of stress.

It is well known that one of the main mechanisms that govern the performance of granular materials, such as sand, is dilatancy. Owing to dilatancy, the initially dense samples of sand increase in volume during shearing, while the loose samples decrease in volume. These phenomena were first noticed by Reynolds 1885 [1] on steal grains, and since then it has been studied by many researchers [2-4]. While investigating the behavior of sand in a direct shear box for different initial densities of samples and different axial compressions, Rowe discovered that the samples shearing from the same initial compression load attain the same final strength; this is independent of the initial density of the sample [2]. This final strength is called the critical strength, while the state of shearing with no additional change in volume is called the critical state. The critical state can be well described for sands with a critical state line in the $e_{c s}-p_{c s}$ ' plane ( $e_{c s}-$ void ratio and $p_{c s}$ ' - mean effective stress at the critical state). During shearing, the sand attains the critical state line under both drained (by increasing/decreasing the volume) and undrained conditions (by increasing/decreasing the pore water pressure) [5-8].

\section{MATERIAL PROPERTIES OF JEROVEC SAND}

Testing the properties of Jerovec sand materials was performed in the following laboratories:

- Faculty of Mining, Geology, and Petroleum Engineering, University of Zagreb (minimum void ratio)

- Croatian Geological Survey (mineralogy and microscopic photo documentation)

- Geotehnički studio d.o.o. (all other tests)

The grain size distribution was determined from four tests according to the ASTM D 422-63 (2007) Standard Test Method for Particle-Size Analysis of Soils; characteristic grain diameters $D(\mathrm{~mm}): \mathrm{D}_{10}=0.147, \mathrm{D}_{30}=0.244$, $D_{60}=0.444 ;$ coefficient of curvature $\left(c_{c}\right): 0.91$ and coefficient of uniformity $\left(c_{u}\right): 3.03$.

The specific gravity of solid particles $\left(\rho_{\mathrm{s} 20^{\circ} \mathrm{C}}\right)$ was tested according to the ASTM D854-14 Standard Test Method for Specific Gravity of Soil Solids by Water Pycnometer; $\rho_{\mathrm{s} 20^{\circ} \mathrm{C}}=2,59 \mathrm{~g} / \mathrm{cm}^{3}$.
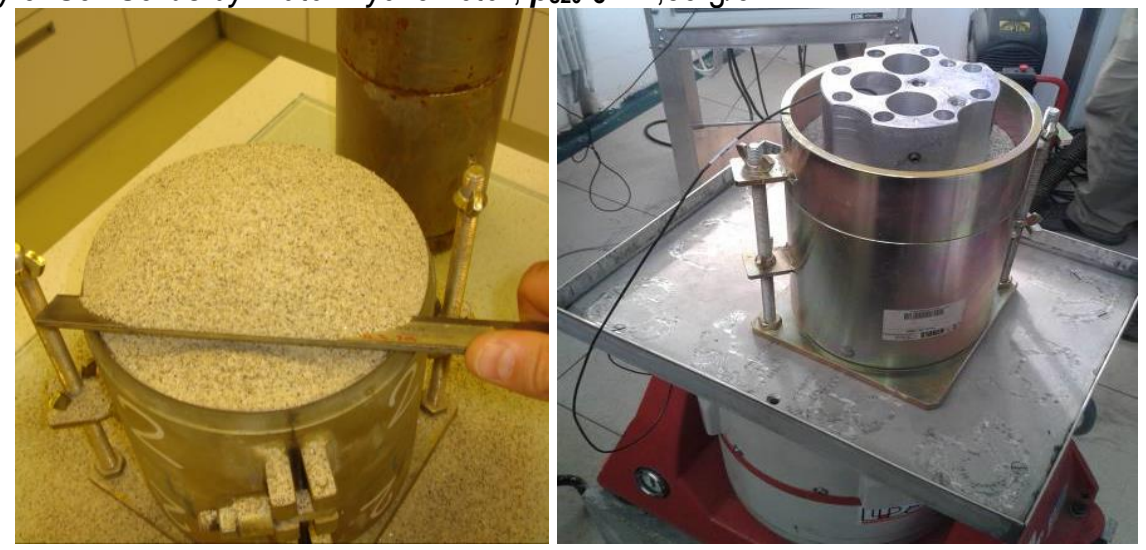

Figure 1 Testing of minimum (left) and maximum (right) index densities of sand

Ofak, J, Zlatović, S, Sokolić, I 
The minimum void ratio $\left(e_{\text {min }}\right)$ was tested according to the ASTM D 4253-00 (2006) Standard Test Methods for Maximum Index Density and Unit Weight of Soils Using a Vibratory Table; $e_{\min }=0,497$.

The maximum void ratio $\left(e_{\max }\right)$ was tested according to the ASTM D 4254-00 (2006) Standard Test Method for Minimum Index Density and Unit Weight of Soils and Calculation of Relative Density, Method A; $e_{\max }=0,844$. The testing procedure for minimum and maximum void ratios is shown in Figure 1.

Sand analysis was made using a scanning electron microscope (SEM). A detector of secondary electrons was employed and a voltage of $20 \mathrm{kV}$ was applied. The chemical composition of mineral grains was determined by an energy dispersive spectrometer (EDS). Morphological analysis shows that the grains are extremely irregular and have almost no roundness. The grains are structurally polycrystalline, and some of the crystal shapes are characteristic of quartz. The polycrystalline composition is also a reason for the surface being uneven. Figure 2 (left) shows a characteristic microscopic photograph of a grain of Jerovec sand. The chemical analysis with EDS showed that all analyzed grains were $\mathrm{SiO}_{2}$ or quartz (Figure 2, right). Sand grains also contain an almost negligible amount of aluminum, calcium, and iron.
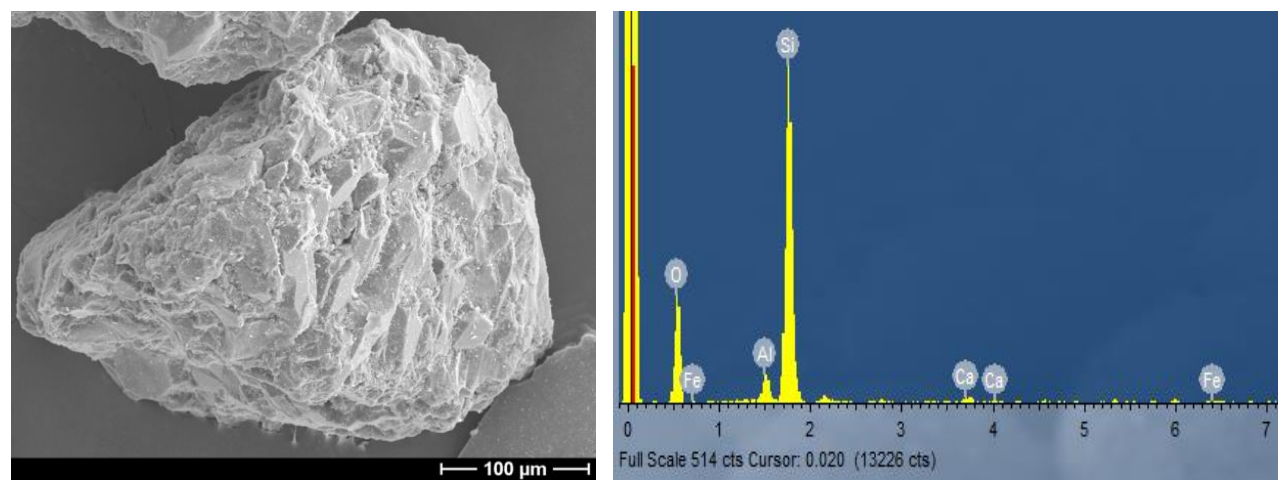

Figure 2 Microscopic photograph of sand grain Jerovec (left) and the results of mineralogy test (right)

\section{TRIAXIAL TEST}

Triaxial tests were performed in Geotehnicki studio d.o.o. laboratory by using advanced triaxial equipment produced by Controls Group - Wykeham Farrance. An automatic triaxial (AUTOTRIAX) system is capable of automatically running drained and undrained consolidated triaxial tests (CID, CIU). The test setup is shown in Figure 3 . The resolution of the measurement equipment is as follows: load $(0,1 \mathrm{~N})$, displacement $(0,01 \mathrm{~mm})$, cell/pore/back pressure $(0,1 \mathrm{kPa})$, volume change $(0,001 \mathrm{cc})$.

The CID triaxial test was performed according to the ASTM D 7181-11 Standard Test Method for Consolidated Drained Triaxial Test for Soils, while the CIU test was performed according to the ASTM D 4767 - Standard test Method for Consolidated Undrained Triaxial Compression Test for Cohesive Soils.

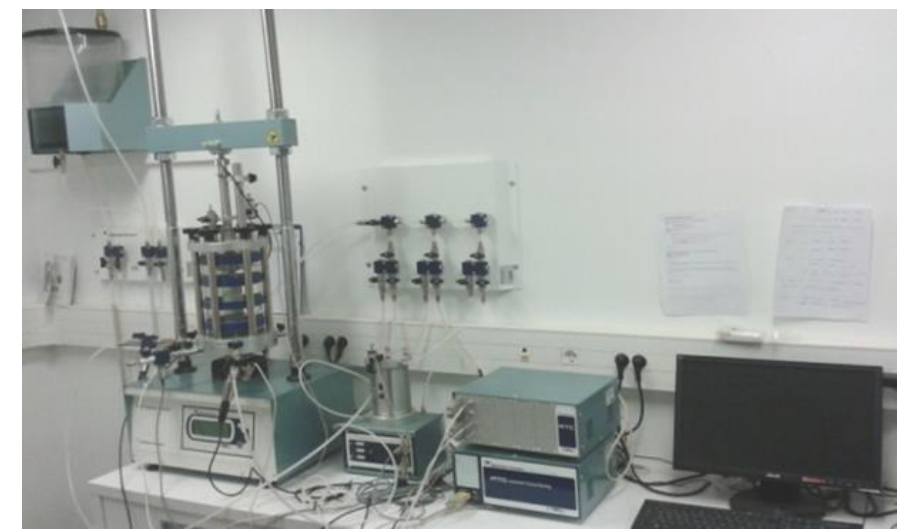

Figure 3 Triaxial apparatus at the Geotehnicki studio Ltd.

Ofak, J, Zlatović, S, Sokolić, I 
The first and most sensitive part of the test is sample preparation. It is very important to produce a sample that is as homogenous as possible and not disturb the sample while manipulating the equipment. Everything must be performed with great care, and the critical part of installation is material tamping, removal of the split mold, placement of the rubber membrane, and installation of the triaxial cell.

The sand samples were prepared using two different methods. The dry method was used for initially loose samples with $e_{\text {inst }}=0,84$ and $I D_{\text {inst }}=0 \%$, by gently pouring the sand material in the mold (same procedure used in ASTM D 4254). The wet tamping method was used to install the samples with $e_{\text {inst }}=0,79$ and $I D_{\text {inst }}=16 \%$, by slowly tamping the wet sand with water content of $5 \%$. To achieve the target initial density and homogenous samples, it was necessary to perform numerous trial tests and define the right technique (number of layers and tamping type) and optimum water content. The characteristic stages of sample preparation are shown in Figure 4 (pouring the sand into the mold, gently tamping the sand in layers, and removing the split sample mold).

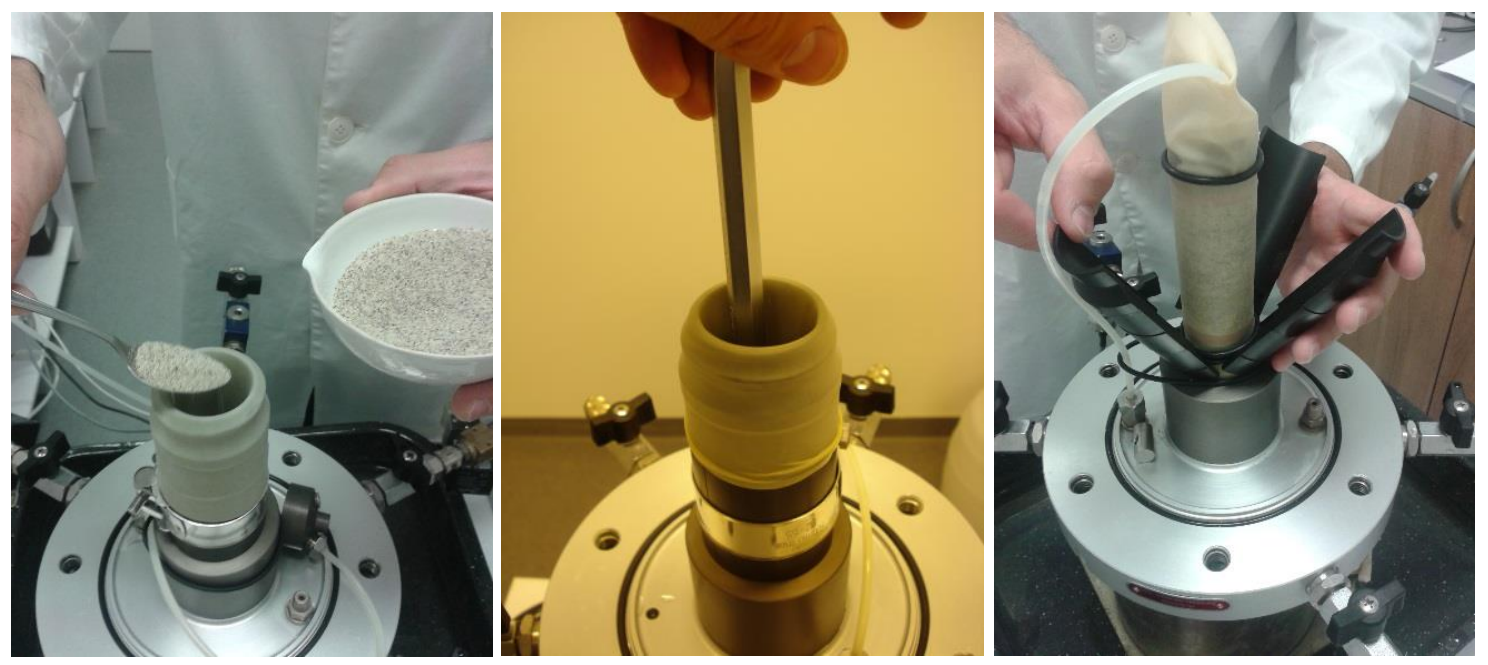

Figure 4 Characteristic steps of sand specimen installation

The next challenging part of the test is saturating the specimen. This is done in two stages: saturating the sample with water during the tamping and flushing the sample with deaerated water after placement in the final position in the cell. The degree of saturation $\left(S_{r}\right)$ is the ratio of the water volume to the pore volume in the soil specimen. The saturation of the sample was checked in each test by using the $B$ value method. The $B$ value is the ratio of the pore pressure increase due to an increase in the cell pressure. To achieve full saturation, each specimen was loaded in small and slow steps of cell pressure increase with vents closed, while measuring the change in pore pressure. To prevent the effective stresses from changing, the back pressure was imposed in parallel to the increase in cell pressure for the same amount. The procedure was performed until the B value equaled 1 , corresponding to $100 \%$ saturation.

The consolidation of the samples was performed slowly enough to prevent disturbance of the soil structure. The consolidation was isotopic to the initial mean effective stress $\left(p^{\prime}\right)$ ). During the consolidation, the volume of water going out of the sample was measured to calculate the void ratio at the end of the consolidation $\mathrm{e}_{0}$. Three different initial mean effective stresses were used in the research: $p^{\prime}{ }_{0}=100,250$, and $750 \mathrm{kPa}$.

Specimen shearing is in general governed by an increase in the axial load or imposing axial deformation. In this investigation, monotonic tests were carried out up to failure.

Two main types of standard tests were conducted to study shear:

(a) Drained tests during which drains are open during shearing, i.e., water can flow in or out of the specimen (consolidated drained if drained in consolidation phase, CID if the specimen is isotropically loaded in the consolidation phase) and

(b) Undrained tests during which drains are closed during shearing, i.e., if the test sample is saturated, the volume of the specimen does not change (consolidated undrained if drained in consolidation phase, CIU if the test specimen is isotropically loaded in the consolidation phase).

Both groups of tests were performed in this investigation. The list of the tests performed is given in Table 1.

Ofak, J, Zlatović, S, Sokolić, I 
Table $1 \mathrm{CID}$ and CIU triaxial tests performed in the research

STATE OF SAMPLE INSTALLED INITIAL STATE

\begin{tabular}{|c|c|c|c|c|c|c|c|c|}
\hline TEST & MARK & einst & $\begin{array}{c}I D_{\text {inst }} \\
{[\%]}\end{array}$ & $e_{0}$ & $\begin{array}{l}I D_{0} \\
{[\%]}\end{array}$ & $\begin{array}{c}p_{0}^{\prime} \\
{[\mathrm{kPa}]}\end{array}$ & $e_{c s}$ & $p_{\mathrm{cs}}[\mathrm{kPa}]$ \\
\hline \multirow{4}{*}{ CID } & CID_1 & 0,79 & 16 & 0,776 & 22 & 100 & 0,870 & 156 \\
\hline & CID_2 & 0,79 & 16 & 0,762 & 26 & 250 & 0,790 & 431 \\
\hline & CID_3 & 0,79 & 16 & 0,747 & 31 & 750 & 0,710 & 1234 \\
\hline & CID_4 & 0,84 & 0 & 0,801 & 14 & 250 & 0,790 & 424 \\
\hline \multirow{5}{*}{ CIU } & ClU_1 & 0,79 & 16 & 0,772 & 23 & 100 & 0,770 & 495 \\
\hline & CIU_2 & 0,79 & 16 & 0,755 & 28 & 250 & 0,750 & 510 \\
\hline & CIU_3 & 0,79 & 16 & 0,721 & 39 & 750 & 0,720 & 849 \\
\hline & ClU_4 & 0,84 & 0 & 0,801 & 14 & 250 & 0,800 & 343 \\
\hline & CIU_5 & 0,84 & 0 & 0,765 & 25 & 750 & 0,765 & 648 \\
\hline
\end{tabular}

\section{TEST RESULTS}

A total of nine triaxial shear tests were performed: four CID and five CIU. The test results are presented in the following diagrams (Figure 5):

- diagram of deviatoric stress $q$ versus mean effective stress $p^{\prime}$,

- diagram of void radio e versus mean effective stress p',

- diagram of deviatoric stress $q$ versus relative deviatoric deformation $\varepsilon_{q}$,

- diagram of change in volume $\varepsilon_{v}$ versus relative deviatoric deformation $\varepsilon_{q}$,

- diagram of change in pore pressure $\Delta u$ versus relative deviatoric deformation $\varepsilon_{q}$.
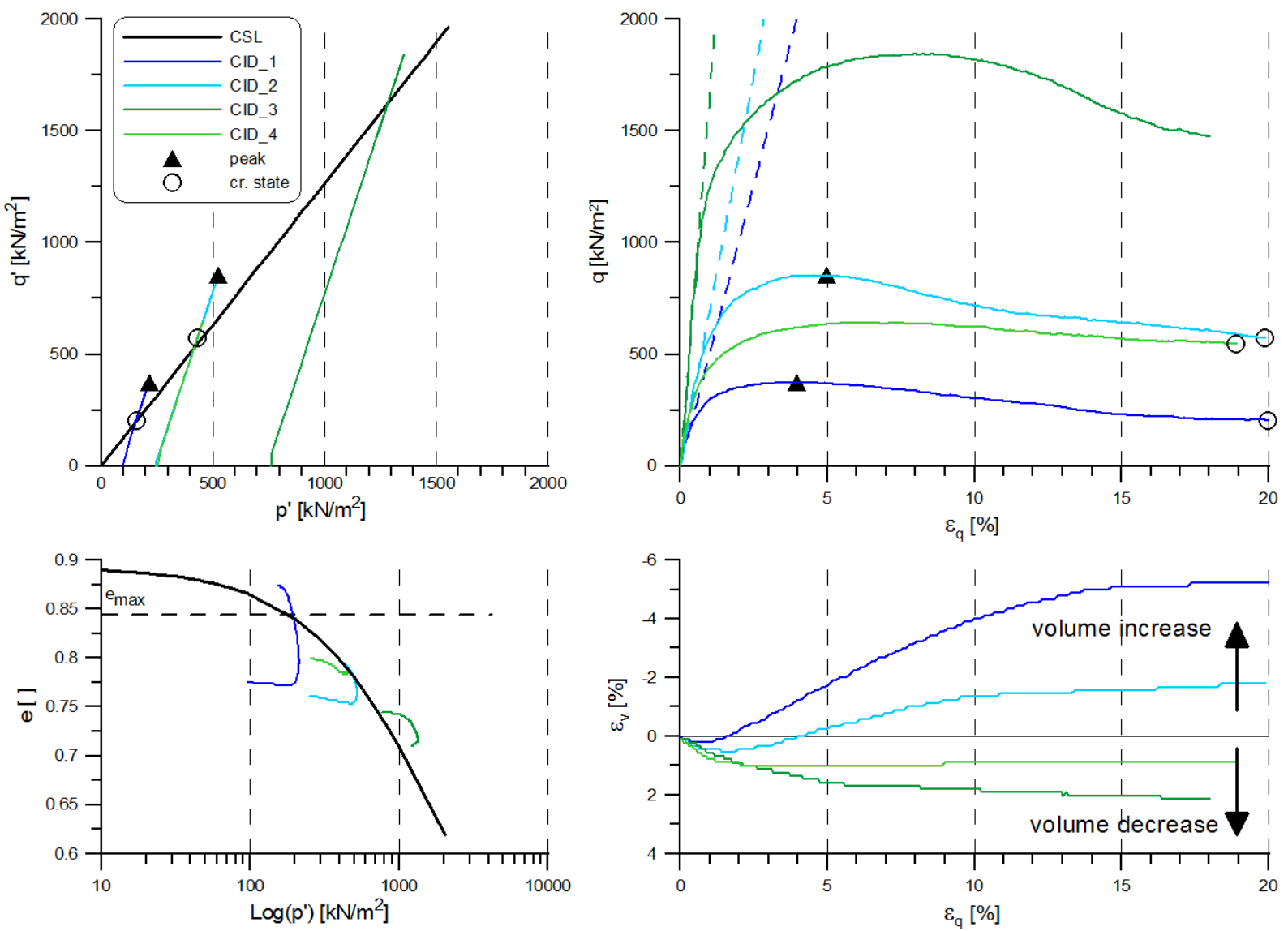

Figure 5 CID test results on Jerovec sand

Ofak, J, Zlatović, S, Sokolić, I 

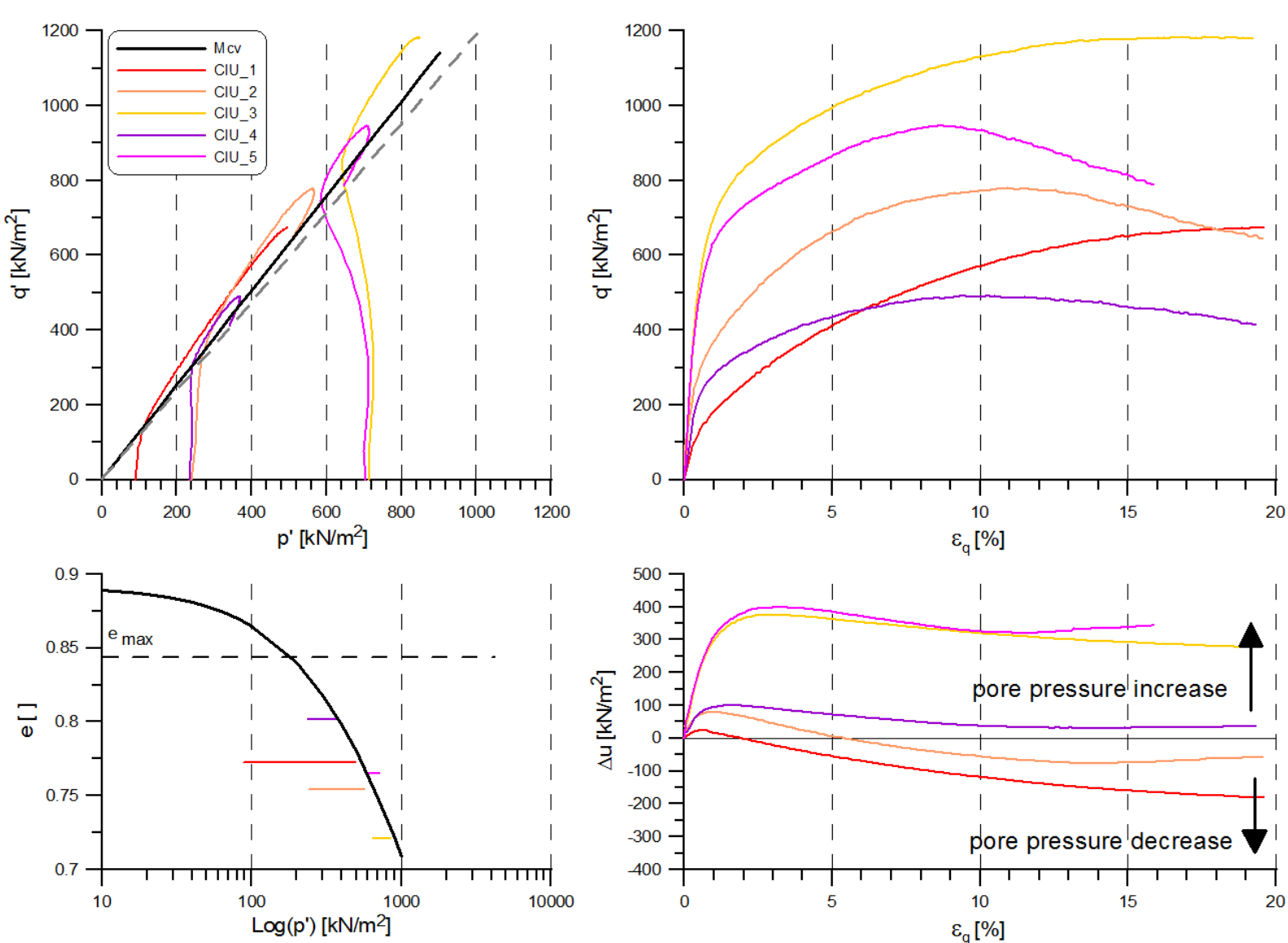

Figure 6 CIU test results on Jerovec sand

The characteristic aspects of sand behavior are clearly shown in Figure 5 for drained conditions and in Figure 6 for undrained conditions of shearing. The CID_1 and CID-2 test results shown in Figure 5 indicate that the initial state of stress for both samples is well below the critical state line CSL line. The samples behave like "dense sand" by increasing the volume while shearing (volume increase is evident on $\varepsilon_{v}-\varepsilon_{q}$ and $p-e$ graphs). On the other hand, the initial state of the sample CID_4 is above the CSL line and the sample behaves like "loose sand" (the sample is compacting while shearing). For dense sand, it is characteristic that it reaches the peak strength before attaining the critical state strength (the peak strength is marked with a black triangle in Figure 5, while the critical state strength is marked with a circle). In addition, it can be observed that the final strength of the sample that starts from the same initial state of stress is independent of the initial density (compare the CID_2 and CID_4 tests). Comparing the stiffness of the samples CID_1, CID_2, and CID_3 (represented by the dashed lines from the origin to the $50 \%$ of strength of the sample), it can be clearly seen that for samples with similar initial density $\left(I_{0}=20-31 \%\right)$, the stiffness increases with an increase in the initial state of stress $\left(p_{0}^{\prime}=100,250,750 \mathrm{kPa}\right)$.

In undrained conditions, there is no change in the volume of the sample, but owing to dilatancy, there is a change in pore water pressure and corresponding change in effective stress. The "dense samples" CIU_1 and CIU_2 (Figure 6), which are well below the CSL line, increase in pore pressure, while CIU_3, CIU_4, and CIU 5 samples decrease in pore pressure. The effective stress goes in the opposite direction, leading to an increase in the strength of the samples in the CIU_1 and CIU_2 tests.

On observing the end of the test for both CID and CIU tests, it can be stated that all curves asymptotically approach the final value (critical state): stress-deformation curve, volume change curve, and pore pressure change curve. On plotting the state of the sample at the end of the test in p'-e and p'-q' diagrams, the characteristic CSL line can be derived as the best-fit estimation, as shown in Figure 7.

The CSL line in the p'-e plane can be well approximated by following the equation proposed by Sheng et al. [9]:

Ofak, J, Zlatović, S, Sokolić, I 
$e_{\mathrm{cv}}=\frac{\Gamma}{\left(\frac{s_{\mathrm{c}}+p}{p_{\text {ref }}}\right)^{\lambda}}$

The CSL line in p'-q' plane (critical state strength line) can be well approximated by following the equation proposed by Roscoe et al. [10]:

$q_{\mathrm{cv}}=M_{\mathrm{cv}} p^{\prime}$

where $M_{c v}$ is the critical state strength parameter, which corresponds to the critical state friction parameter:

$M_{\mathrm{cV}}=\frac{6 \operatorname{Sin}\left(\varphi_{\mathrm{cv}}\right)}{3-\operatorname{Sin}\left(\varphi_{\mathrm{cv}}\right)}$

The following parameters of Jerovec sand are derived in this research: $M_{c v}=1,26 ; \varphi_{c v}=31,5 ; \Gamma=1,922$; $\lambda=0,333 ; s_{c}=1.004$.

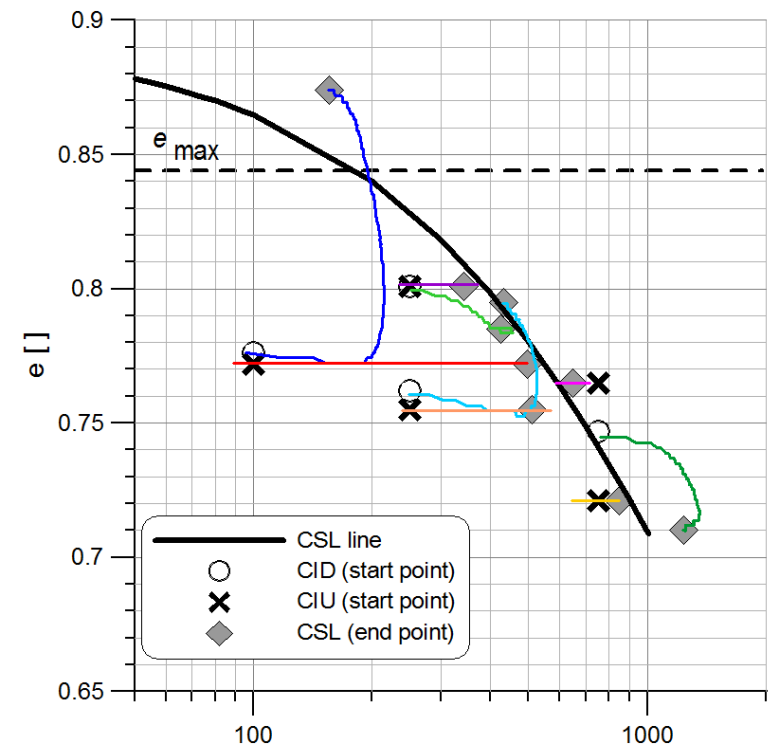

a)

$\log \left(p^{\prime}\right)\left[\mathrm{kN} / \mathrm{m}^{2}\right]$

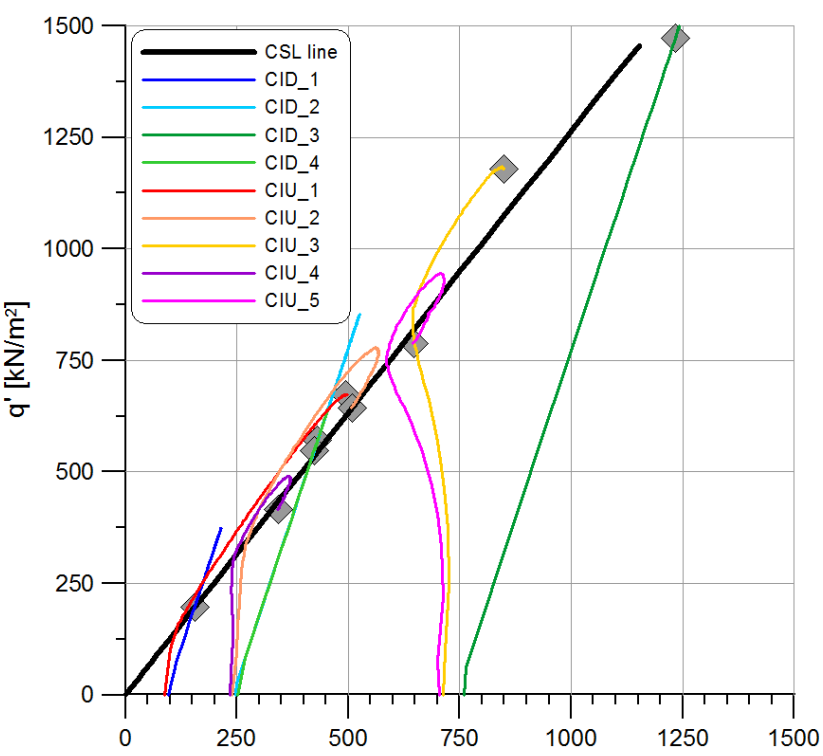

b)

$p^{\prime}\left[\mathrm{kN} / \mathrm{m}^{2}\right]$

Figure 7 Critical state line of Jerovec sand and the critical state strength

Finally, this research compares the investigation results of Jerovec sand with those of some well-known sands available in the literature [7]. The results of the comparison is shown in Figure 8 and given in Table 2. It can be seen that the CSL line of Jerovec sand falls within the expected range compared to the CSL lines of other sands. Jerovec sand behaves very similar to the Ticino sand, which is also quartz sand with a similar $D_{50}$ and maximum void ratio $\mathrm{e}_{\max }$.

Table 2 Comparison of the parameters of Jerovec sand with some sands available in the literature

\begin{tabular}{cccccccccc} 
Sand & $\begin{array}{c}\boldsymbol{D}_{50} \\
{[\mathrm{~mm}]}\end{array}$ & $\begin{array}{c}\mathrm{FG}^{* * *} \\
{[\%]}\end{array}$ & $\mathbf{G}$ & $\mathbf{e}_{\max }$ & $\mathbf{e}_{\min }$ & $\boldsymbol{\varphi}_{\mathrm{cv}}$ & $\begin{array}{c}\boldsymbol{S}_{\mathrm{c}} \\
{[\mathrm{Mpa}]}\end{array}$ & $\boldsymbol{\Gamma}$ & $\boldsymbol{\lambda}$ \\
\hline Jerovec & $\mathbf{0 , 4 2}$ & $\mathbf{0 , 3 5}$ & $\mathbf{2 , 5 9}$ & $\mathbf{0 , 8 4 4}$ & $\mathbf{0 , 4 9 7}$ & $\mathbf{3 1 , 5}$ & $\mathbf{1 , 0 0 4}$ & $\mathbf{1 , 9 2 2}$ & $\mathbf{0 , 3 3 3}$ \\
\hline Toyoura & 0.16 & 0 & 2.65 & 0.987 & 0.608 & 31,0 & 3,339 & 3,266 & 0,359 \\
\hline Ticino & 0.53 & 0 & 2.67 & 0.890 & 0.600 & 31,0 & 0,536 & 1,273 & 0,202 \\
\hline Erksak & 0.70 & 0.7 & 2.66 & 0.747 & 0.521 & 31,5 & 4,236 & 4,335 & 0,461 \\
\hline Boštanj & 0.12 & 30 & 2.75 & 0.742 & 0.500 & 34,5 & 0,204 & 0,863 & 0,213 \\
\hline Portaway & 0.40 & 1.5 & 2.65 & 0.790 & 0.460 & 29,8 & 0,961 & 1,126 & 0,209 \\
\hline
\end{tabular}

${ }^{* * *} \mathrm{FG}$ - fine grains, those smaller than 0,06 mm [\%]

Ofak, J, Zlatović, S, Sokolić, I 


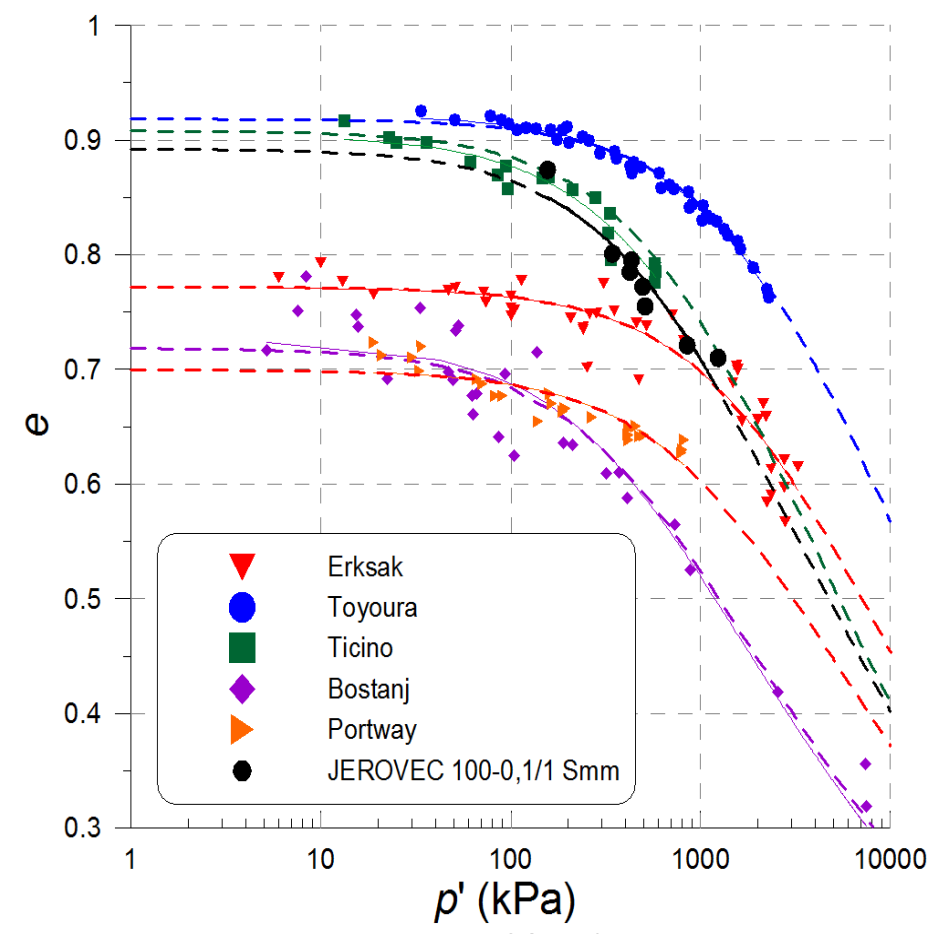

Figure 8 CSL line of Jerovec sand compared with the CSL of some sand available in the literature

\section{CONCLUSION}

The characteristic aspects of sand behavior in a triaxial test were successfully presented in this research for Jerovec sand. Nine triaxial tests were performed for different drainage conditions (four CID tests and five CIU tests). Tests were performed for different densities of sand $\left(I D_{\text {inst }}=0 \div 0,16\right)$ and for different isotropic consolidation pressures $\left(\sigma_{c}^{\prime}=100,250,750 \mathrm{kPa}\right)$. The test results are presented in a set of diagrams, which clearly shows the aspects of sand behavior: $q-p, e-p, q-\varepsilon_{q}, \varepsilon_{v}-\varepsilon_{q}$ for CID tests, and $q-p^{\prime}, e-p^{\prime}, q-\varepsilon_{q}, \Delta u-\varepsilon_{q}$ for CIU tests. The CSL line is derived as a best-fit estimate for points at the end of each test, i.e., the critical state. It can be concluded that the CSL line and the critical state strength of Jerovec sand are in the expected range compared to the well-known sands available in the literature. In addition, the dispersion of the test results gives us great confidence that the test program was carried out in a proper manner with sufficient capabilities of the testing equipment.

\section{References}

[1] Reynolds, 0. 1885: On the dilatancy of media composed of rigid particles in contact, with experimental illustrations. Philosophical Magazine, 20 (27), pp. 469-481, https://doi.org/10.1080/14786448508627791

[2] Rowe, P. W. 1962: The stress-dilatancy relation for static equilibrium of an assembly of particles in contact. Proceedings of the Royal Society a Mathematical, Physical and Engineering Science, pp. 269-1339, https://doi.org/ 10.1098/rspa.1962.0193

[3] De Joselin de Jong, G. 1976: Rowe's stress-dilatancy: Relation based on friction. Géotechnique, 26 (3), https://doi.org/10.1680/geot.1976.26.3.527

[4] Collins, I. F.; Muhunthan, B.; Tai, A. T.; Pender, M. J. 2007: The concept of a 'Reynolds-Taylor state' and the mechanics of sands. Géotechnique, 57 (5), pp. 437-447, https://doi.org/10.1680/geot.2007.57.5.437

[5] Jefferies, M.; Been, K. 2006: Soil Liquefaction - A critical state approach. CRC Press

[6] Kvasnička, P.; Domitrović, D. 2007: Soil Mechanics, University of Zagreb, Faculty of Mining, Geology and Petroleum Engineering, Zagreb (in Croatian)

[7] Sokolić, I. 2010: A sand model embedded into the generalized Iwan system, PhD thesis, University of Zagreb, Faculty of Civil Engineering, Zagreb (in Croatian)

[8] Zlatović, S. 2006: Introduction to Soil Mechanics, The Polytechnic of Zagreb, Zagreb (in Croatian) 
[9] Sheng, D.; Yao, Y.; Carter, J. P. 2008: A volume-stress model for sands under isotropic and critical states. Canadian Geotechnical Journal, 45 (11), pp. 1639-1645, https://doi.org/10.1139/T08-085

[10] Roscoe, K. H.; Schofield, M. A.; Wroth, M. A. 1958: On the yielding of soils. Géotechnique, 8 (1), pp. 22-53, https://doi.org/10.1680/geot.1958.8.1.22

Please cite this article as:

Ofak, J, Zlatović, S, Sokolić, I: Testing of Jerovec sand and defining its critical state line, Electronic Journal of the Faculty of Civil Engineering Osijek-e-GFOS, 15, pp. 50-58, https://doi.org/10.13167/2017.15.5

Ofak, J, Zlatović, S, Sokolić, I 